\title{
Crossed immunoelectrophoresis of major protein antigens during pupation of the leafcutting bee Megachile rotundata
}

\author{
G.H. Rank, D.W. Goerzen and J.H. Gerlach * \\ Department of Biology, University of Saskatchewan, Saskatoon, Saskatchewan, Canada S7N OWO
}

(received 12 November 1987, accepted 21 December 1988)

Summary - Antibodies to total homogenized prepupae of Megachile rotundata identified six major antigens in crossed immunoelectrophoresis. From the beginning of pupal differentiation until adult emergence, quantitative variation in six antigens was observed. Prepupal proteins from Megachile relativa demonstrated immunological identity with four of the six antigens identified in Megachile rotundata although one antigen differed in electrophoretic mobility.

Prepupal proteins were separated by isoelectric focusing in the first dimension and then run into a second-dimension, antibody-containing gel. Two antigens were correlated with polypeptides 4 $(M r=43,000, p l=6.00)$ and $1(M r=107,000, p l=6.55)$ of two-dimensional polyacrylamide gel electrophoresis analyses.

Megachile rotundata - development - protein fluctuation - crossed immunoelectrophoresis - voltinism

Résumé - Immunoélectrophorèse croisée des principaux antigènes protéiques au cours de la nymphose de Megachile rotundata. Nous nous intéressons aux événements moléculaires qui sont à la base de l'émergence de Megachile rotundata dans les conditions naturelles. Nous avons utilisé l'immunoélectrophorèse croisée comme technique quantitative pour suivre les fluctuations des protéines nymphales.

Pendant 9 mois, nous avons injecté à des lapins les protéines totales homogénéisées des prénymphes de M. rotundata. Un pool de $817 \mathrm{ml}$ d'antisérum a été récolté et utilisé pour obtenir une fraction d'immunoglobulines. Celle-ci a été utilisée pour précipiter les protéines au cours d'une immunoélectrophorèse croisée. Nous avons pu définir 6 pics d'immunoprécipitation et évalué leur variation quantitative au cours de la nymphose.

On n'a noté aucune fluctuation jusqu'au $10^{\circ}$ jour de l'incubation nymphale à $30^{\circ} \mathrm{C}$. Puis 5 des 6 pics ont diminué durant la fin de la période d'incubation. On a comparé les pics identifiés par l'immunoélectrophorèse croisée avec ceux obtenus précédemment par électrophorèse bidimensionnelle en gel de polyacrylamide. En séparant les protéines prénymphales par isoélectrofocalisation dans la fre dimension et en faisant migrer les protéines dans un gel de seconde dimension contenant les anticorps, on a pu associer 2 antigènes aux polypeptides $4 \mathrm{Mr}=43.000$

* Present address : Department of Oncology, Queen's University, Kingston, Ontario, Canada K7L 2 V7. 
$\mathrm{pl}=6,00)$ et $1 \mathrm{Mr}=107.000 \mathrm{pl}=6,55)$ obtenus en électrophorèse bidimensionnelle en gel de polyacrylamide.

Megachile rotundata - développement - fluctuation des protélnes - immunoélectrophorèse crolsée

Zusammenfassung - Kreuz-Immun-Elektrophorese der wichtigsten Protein-Antigene während der Verpuppung der Blattschneideblene Megachlle rotundata. Thema dieser Arbeit sind die molekularen Grundlagen des Auftauchens von Megachile rotundata während der Feldsaison. Zur quantitativen Erfassung der Verschiebungen in den pupalen Proteinen bedienten wir uns der Kreuz-Immun-Elektrophorese.

Völlig homogenisiertes Protein von Megachile rotundata - Präpuppen wurde Kaninchen neun Monate lang eingespritzt. Um eine ausreichende Immunglobulinfraktion zu erhalten, wurden $817 \mathrm{mI}$ Antiserum gewonnen. Die Immunglobulinfraktion wurde verwendet, um in einer Kreuz-ImmunElektrophorese die Proteine auszufällen. Sechs wohldefinierte Immunpräzipitat-Peaks wurden gefunden und während der Pupalentwicklung beobachtet.

Bis zum zehnten Tag der Inkubation der Puppen wurden bei $30^{\circ} \mathrm{C}$ keine Veränderungen beobachtet. Danach verringerten sich fünt der sechs Peaks über den Rest der Inkubationszeit. Ein Vergleich der Peaks aus der Kreuz-Immun-Elektrophorese mit einer vorherigen zweidimensionalen Polyacrylamid-Gel-Elektrophorese wurde durchgeführt. Bei der Auftrennung von präpupalen Proteinen durch isoelektrische Fokussierung in der ersten Dimension und anschließendes Laufenlassen der Proteine in der zweiten Dimension, Antikörper-haltiges Gel, zeigte sich ein Zusammenhang zweier Antigene mit Polypeptid $4 \mathrm{Mr}=43000, \mathrm{pl}=6.00)$ und Polypeptid $1 \mathrm{Mr}=$ $107000, \mathrm{pl}=6.55$ ) aus der zweidimensionalen Polyacrylamid-Gel-Elektrophorese.

Megachile rotundata, Verpuppung - Protein-Verschlebung - Kreuz-Immun-Elektrophorese

\section{Introduction}

The alfalfa leafcutting bee, Megachile rotundata, is an effective pollinator of alfalfa under a wide range of environmental conditions. A problem encountered in the management of this species is the variable field emergence of bees (Johansen et al., 1973; Taséi and Masure, 1978; Taséi, 1982). This results in the production of a second generation of bees that is unable to reproduce before the onset of winter and generally is not effective in pollination. Furthermore, the second generation is believed to be a vector in the spread of chalkbrood (Vandenberg et al., 1980). As a prerequisite to studying the physiological control of diapause development in this species we have investigated protein changes during pupation.
Total protein fluctuations during pupation in $\boldsymbol{M}$. rotundata have previously been analyzed by the technique of twodimensional polyacrylamide gel electrophoresis (2D-PAGE) utilizing isoelectric focusing in the first dimension and sodium dodecyl sulphate (SDS)-polyacrylamide gel electrophoresis in the second dimension. Eleven polypeptides were observed to vary during development at $30{ }^{\circ} \mathrm{C}$. The major polypeptide identified (apparent mol wt of 107,000 and isoelectric point of 6.55) decreased during development and was absent in newly emerged adults (Rank et al., 1982). A major limitation of 2D-PAGE for physiological studies is the difficulty in quantitatively evaluating protein fluctuations. Crossed immunoelectrophoresis (CIE) provides a convenient quantitative evaluation of antigenic components (Laurell, 1966). This technique has been 
used successfully in the analysis of mite allergens (Lind, 1980; Arlian et al., 1985) and wasp venom (Einarsson et al., 1985). $\mathrm{CIE}$ has not been used to evaluate protein fluctuations during insect pupation.

This study reports the identification of the major antigenic determinants in the prepupae of $M$. rotundata, the quantitative variation of these antigens during pupation, and an evaluation of proteins identified in common by 2D-PAGE and $\mathrm{CIE}$ analyses. The antigens of the related species $M$. relativa were also examined.

\section{Materials and Methods}

\section{Antibody preparation}

Fifty $M$. rotundata prepupae (stored at $5^{\circ} \mathrm{C} c$ $5 \mathrm{mo}$ ) were homogenized in $40 \mathrm{ml}$ of phosphate-buffered saline $(\mathrm{pH} 7.2)$, strained through wire mesh and sonicated for 4-5-s intervals. Samples at a protein concentration of $8 \mathrm{mg} \cdot \mathrm{ml}^{-1}$ were frozen in liquid nitrogen and stored at $-80^{\circ} \mathrm{C}$. The prepupal homogenate was mixed 1:1 (v/v) with Freund's incomplete adjuvant and three rabbits were each injected intradermally with $500 \mu \mathrm{g}$ of protein at 2-wk intervals. Eight days after the fourth injection serum was collected by bleeding through the marginal ear vein. Injections were continued at 3-4-wk intervals over a period of $9 \mathrm{mo}$ and serum was collected every 8-10 d postinjection to produce an antiserum pool of 817 $\mathrm{ml}$. An immunoglobulin fraction, in a final volume of $130 \mathrm{ml}$, was isolated from this pool according to the procedure of Harboe and Inglid (1973). Plasmin was inactivated by the addition of aprotinin (200 KIU॰ml-1).

\section{Incubation and sample analysis}

Cells containing prepupae of $\boldsymbol{M}$. rotundata and $M$. relativa were obtained from commercial hives (Rank and Goerzen, 1981) in the year following antibody production. After storage at $5{ }^{\circ} \mathrm{C}$ for $5 \mathrm{mo}$, prepupae to be used for electrophoretic analyses were incubated at $30{ }^{\circ} \mathrm{C}$. Prepupae or developing pupae from incubation periods of $0,5,10,13,18$, and $21 d$ were ground in a teflon-glass homogenizer in phosphate-buffered saline (pH 7.2), mixed vigorously, strained through wire mesh, mixed vigorously, and sonicated ( $4 \times 5 \mathrm{~s}$ ) with a Fisher Ultrasonic probe set at the maximum power setting. The samples were quick frozen in liquid nitrogen and stored at $-80{ }^{\circ} \mathrm{C}$ until used in electrophoretic analysis.

\section{Electrophoresis}

Samples prepared for CIE were adjusted to a protein concentration of $5 \mathrm{mg} \cdot \mathrm{ml}^{-1}$ in a buffer containing $1 \%(w / v)$ Triton X-100, $10 \mathrm{mM}$ glycine, and $3.8 \mathrm{mM}$ Tris, $\mathrm{pH}$ 8.7. The samples were sonicated $(4 \times 5 \mathrm{~s})$ on ice with a Fisher Ultrasonic probe set at the maximum power setting, followed with centrifugation at 48,000 $g$ for $60 \mathrm{~min}$ at $4{ }^{\circ} \mathrm{C}$. The supernatant was removed and used within $2 \mathrm{~h}$. Triton $\mathrm{X}-100$, a neutral detergent, was included so that both membrane-bound and soluble proteins would be released.

Crossed immunoelectrophoresis was performed as previously described (Gerlach et al., 1982). First-dimension electrophoresis was at $15 \mathrm{~V} \cdot \mathrm{cm}^{-1}$ for $50 \mathrm{~min}$ in $1 \%(\mathrm{w} / \mathrm{V})$ agarose gels containing $0.5 \%(w / v)$ Triton $X-100$. Second-dimension electrophoresis, on $7 \times 10$ $\mathrm{cm}$ glass plates, was at $2 \mathrm{~V}^{\circ} \mathrm{cm}^{-1}$ for $18 \mathrm{~h}$ in $1 \%$ (W/v) agarose gels containing $200 \mu \mathrm{l}$ of purified antibodies and $0.5 \%(w / v)$ Triton $X$ 100. Immunoprecipitates were stained with Crocein scarlet-Coomassie brilliant blue (Crowle and Cline, 1977). Major immunoprecipitates were traced on Mylar, and peak area (Fig. 3) was determined by using a manual digitizer with a Hewlett-Packard model 9820A computer programmed to calculate the area of polygons. When $\mathrm{CIE}$ is performed according to Laurell (1966), the area of an antigen peak is directly proportional to the amount of the antigen present in the sample.

Samples for crossed immunoelectrofocusing (CIF) were solubilized and subjected to first-dimension isoelectric focusing as previously described (Robertson et al., 1980; Rank et al., 1982). The gels were equilibrated in $2 \%(w / v)$ Triton $X-100,10 \mathrm{mM}$ glycine, and $3.8 \mathrm{mM}$ Tris, $\mathrm{pH} 8.7$ for $45 \mathrm{~min}$. The seconddimension electrophoresis, on $10 \times 10 \mathrm{~cm}$ glass plates, was at $2 \mathrm{~V} \cdot \mathrm{cm}^{-1}$ for $18 \mathrm{~h}$ in $1 \%(\mathrm{w} / \mathrm{V})$ agarose gels containing $600 \mu \mathrm{l}$ of purified antibodies and $0.5 \%(w / v)$ Triton X-100. 


\section{Results}

\section{Standard CIE pattern for prepurae}

The antibody was produced with complete prepupae without any fractionation prior to intradermal injection. Similarly, a neutral detergent solubilization of total prepupal protein was employed which was capable of releasing both membranebound and soluble protein antigens (Gerlach et al., 1982). Thus the CIE analysis represents the major antigens of the prepupae. As seen in Fig. 1, 6 well defined immunoprecipitates were observed. More than 20 independent analyses showed that the pattern of these 6 peaks was reproducible. Pronase digestion of the sample prior to CIE showed that the antigens were proteins (data not shown). The bilateral symmetry of the immunoprecipitates indicates that the proteins were not degraded prior to analysis. The low number of immunoprecipitates observed was consistent with previous 2D-PAGE analysis which identified only 8 major polypeptides in prepupae (Rank et al., 1982).

\section{Protein changes during pupation}

The morphological development apparent after $5,10,13$, and $18 \mathrm{~d}$ of incubation at $30{ }^{\circ} \mathrm{C}$ is given in Table $\mathrm{l}$. No morphological differentiation was observed at d5.

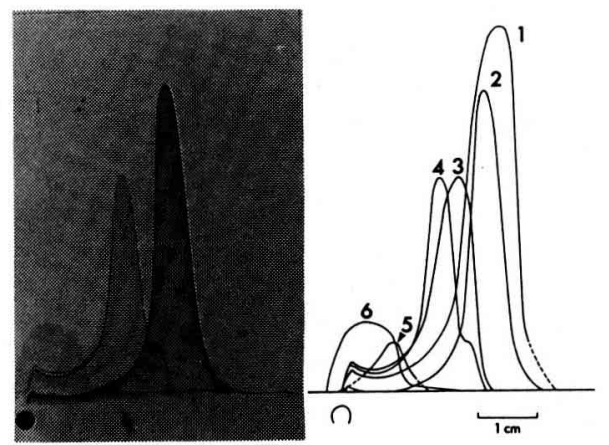

Fig. 1. CIE of $M$. rotundata prepupae. $20 \mu \mathrm{l}$ of Triton X-100 solubilized prepupal homogenate (100 $\mu \mathrm{g}$ protein) was loaded in the application well (0). First dimension electrophoresis was performed at $15 \mathrm{~V} \cdot \mathrm{cm}^{-1}$ for $50 \mathrm{~min}$ and second dimension electrophoresis was at $2 \mathrm{~V} \cdot \mathrm{cm}^{-1} 18$ $h$. The anode was to the right and top of the gel. The second dimension gel contained $200 \mu \mathrm{l}$ of purified antibodies to prepupal homogenates. A diagrammatic representation of the six reproducible immunoprecipitates is given on the right.

CIE analyses of d5 pupae also revealed no variation in the shapes or relative positions of the 6 immunoprecipitates (Fig. 2B). Similarly, an analysis of the area of the 6 immunoprecipitates showed minimal variation between d0 and d5 (Fig. 3). By d10, when morphological differentiation was observed, several of the immunoprecipitates had alterations in the peak area (Fig. $2 \mathrm{C}$ and Fig. 3). Several types of protein fluctuations were

Table I. Morphological characteristics of $M$. rotundata stages during development at $30^{\circ} \mathrm{C}$.

No. days Morphological characteristics

\begin{aligned} & 0 Prepupa in diapause \\ & 5 No morphogenesis - appearance of prepupa as in diapause \\ & 10 Differentiation of head, thorax and abdomen \\ & 13 Melanization of pupal head and thorax; \\ & abdomen lightly striped with melanized bands \\ & 18 Melanization complete; wings undeveloped \\ & Teneral adult Newly emerged adult capable of flight \\ & \hline\end{aligned}



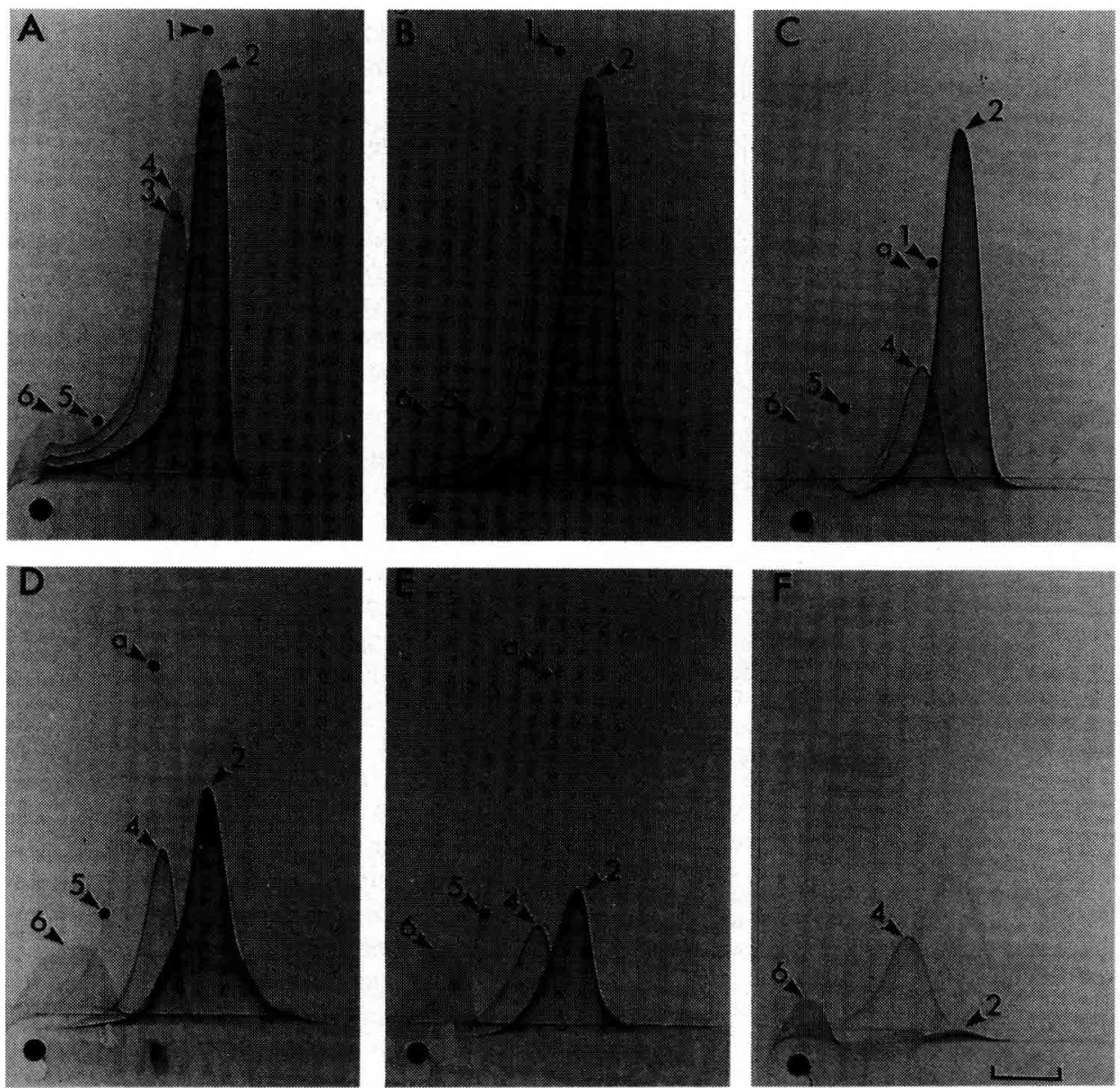

Fig. 2. $\mathrm{CIE}$ of $M$. rotundata during diapause development at $30^{\circ} \mathrm{C}$. A, prepupae; $\mathrm{B}, 5$ days; $\mathrm{C}, 10$ days; $D, 13$ days; $E, 18$ days; $F, 21$ days (teneral adults). Electrophoresis conditions were as in Fig. 1. Bar represents $1 \mathrm{~cm}$.

observed during pupation. The area of peak 1 decreased from 7 to $2 \mathrm{~cm}^{2}$, and peak 3 completely disappeared by day 10 . By d13, peak 1 was no longer evident. Peaks 2 and 4 declined in area but did not disappear during pupation; peak 2 was virtually absent in teneral adults, whereas peak 4 declined to approximately onethird of the original value $\left(3 \mathrm{~cm}^{2}\right.$ to $\left.1 \mathrm{~cm}^{2}\right)$.
Peak 6 did not change appreciably during development but appeared to decline slightly in adults. Peaks 5 and $a$ increased during pupation but were absent in adults. The increase in the a immunoprecipitate is particularly striking as it was not evident in prepupal samples and subsequently increased to a maximum peak area of 7 $\mathrm{cm}^{2}$ by $\mathrm{d} 18$. 


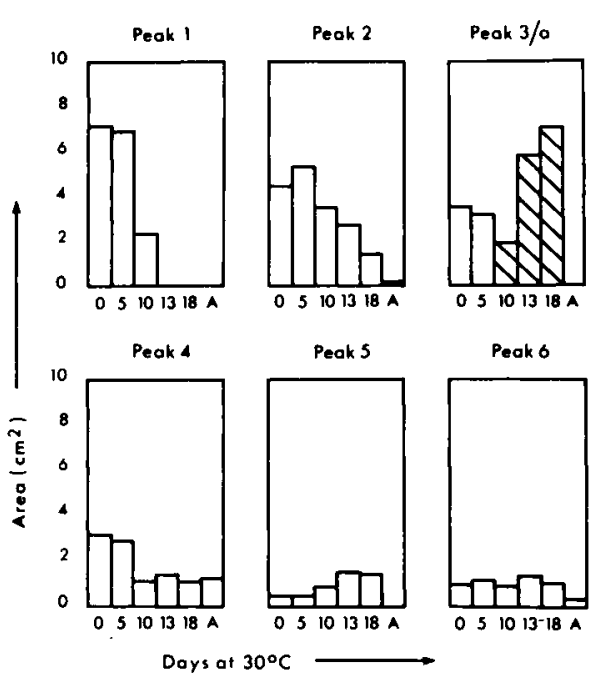

Fig. 3. Quantitative measurement of the immunoprecipitate peaks at 6 different stages of development as shown in Fig. 2. Visual inspection from 5 different analyses showed protein fluctuations to be highly reproducible. Quantification for a single set of analyses was performed as described in Materials and Methods. $A=$ teneral adults that emerged on day 21 . Note that areas at peak 3 and peak a (cross-hatched) have been combined - in a single panel for ease of presentation since peak 3 was absent after day 5 and peak $a$ was not observed until day 10.

Comparison of prepupal antigens of $\mathrm{M}$. rotundata and $\mathrm{M}$. relativa

Solubilized protein from $M$. rotundata and $M$. relativa prepupae were compared by CIE using the antibodies prepared against $M$. rotundata prepupae (Fig. 4). By mixing solubilized protein extracts from the two species it was possible to compare the antigens present in the $M$. relativa prepupae with those of $M$. rotundata. When the two samples were mixed, antigens 2, 3 and 6 gave single, symmetrical immunoprecipitates and therefore were antigens of similar electrophoretic mobility and complete immunological identity. Antigen 4 of $M$. rotundata and antigen $4 a$ of $M$. relativa produce a fused, bimodal immunoprecipitate with no spurs. This indicates that the two antigens have complete immunological identity but possess differing electrophoretic mobilities. Peaks 1 and 5 of $M$. rotundata are absent in $M$. relativa, suggesting that these antigens are either not present or else have little immunological similarity.

\section{Comparison of 2D-PAGE and CIE analyses}

Previous 2D-PAGE analyses had identified variations in 11 major polypeptides during pupation. These polypeptides ranged in apparent molecular weight (Mr) from 29000 to 107000 and apparent isoelectric point $(p l)$ from 5.80 to 7.20 (Rank et al., 1982). The hybrid technique of crossed immunoelectrofocusing (CIF) was used in an attempt to correlate these polypeptides with the antigens detected in the present CIE analyses. Proteins separated in a first-dimension, isoelectric focusing tube gel were run into a seconddimension gel containing antibodies to the prepupae of $M$. rotundata (Fig. 5). A comparative analysis of $M$. rotundata and $M$. relativa and the temporal variation in immunoprecipitate patterns was used to assist in protein identification.

$M$. rotundata preparations produced three tightly clustered, cathodal $(v, w$, and $x)$ and one faint anodal (dotted line) immunoprecipitates (Fig. 5A). The pattern for $M$. relativa was similar except that only two cathodal immunoprecipitates $(y, z)$ were identified (Fig. 5B). Protein denaturation resulting from the urea and SDS employed in solubilization limits the resolution possible with this technique. Nevertheless, tentative cross-identifications of proteins resolved by the 2DPAGE and CIE analyses can be made. 


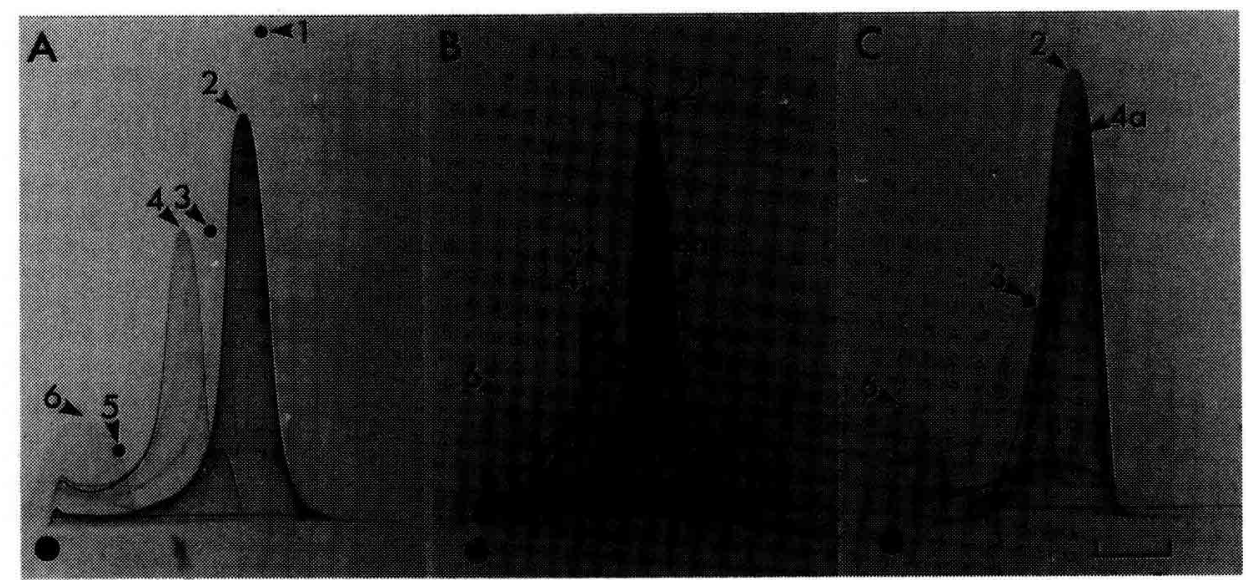

Fig. 4. Comparative $\mathrm{CIE}$ analysis of prepupae of $M$. rotundata and $M$. relativa. A, $M$. rotundata (100 $\mu \mathrm{g}$ protein); B, mixture of $M$. rotundata ( $50 \mu \mathrm{g}$ protein) and $M$. relativa ( $50 \mu \mathrm{g}$ protein); $\mathrm{C}, M$. relativa $(100 \mu \mathrm{g}$ protein). Note that the antibodies employed were raised against prepupal homogenates of $M$. rotundata. Electrophoresis conditions were as in Fig. 1. Bar represents $1 \mathrm{~cm}$.

The faint, anodal immunoprecipitate was common to both species (Fig. 5) and the electrophoretic mobility corresponds to peak 6 of the CIE analysis. Peak 6 area was constant during pupation (Figs. 2 and 3). Polypeptide 4 with an apparent $M r$ of 43,000 and apparent $p /$ of 6.00 is the most likely equivalent component in the 2D-PAGE analysis since this is the only developmentally constant polypeptide with a low $p /$ present in both species (Rank et al., 1982; Table I). The positions of immunoprecipitates $v$ (Fig. 5A) and $y$ (Fig. $5 B$ ) coincide with the major component of the 2D-PAGE gel, polypeptide $1(\mathrm{Mr}=$ $107,000, p l=6.55)$. The prominence of peak 2 in both species in the corresponding area of the CIE gel (Fig. 4) suggests that this immunoprecipitate contains polypeptide 1 . This conclusion is supported by the observation that peak 2 and polypeptide 1 both decrease during development and are absent in teneral adults. The immunoprecipitates $x, w$, or $z$ cannot be clearly correlated with any of the remaining nine major polypeptides of the 2D-PAGE analysis. However, the absence of $M$. rotundata peak 5 (Fig. 4A) and immunoprecipitate $x$ (Fig. 5A) in the corresponding $M$. relativa gels (Figs. 4C and $5 B$ ) indicates that these are the same antigenic component.

\section{Discussion}

Previous 2D-PAGE analysis identified 110 polypeptides in $M$. relativa and 104 polypeptides in $M$. rotundata prepupal homogenates (Rank et al., 1982). In sharp contrast, the present $\mathrm{CIE}$ analysis identified only 6 and 4 antigens in prepupal homogenates of $M$. rotundata and $M$. relativa, respectively. However, of the 104 polypeptides identified by 2DPAGE analysis of $M$. rotundata, only 11 polypeptides fluctuated in amount during pupation. Furthermore, an accurate and convenient quantitative evaluation of the 


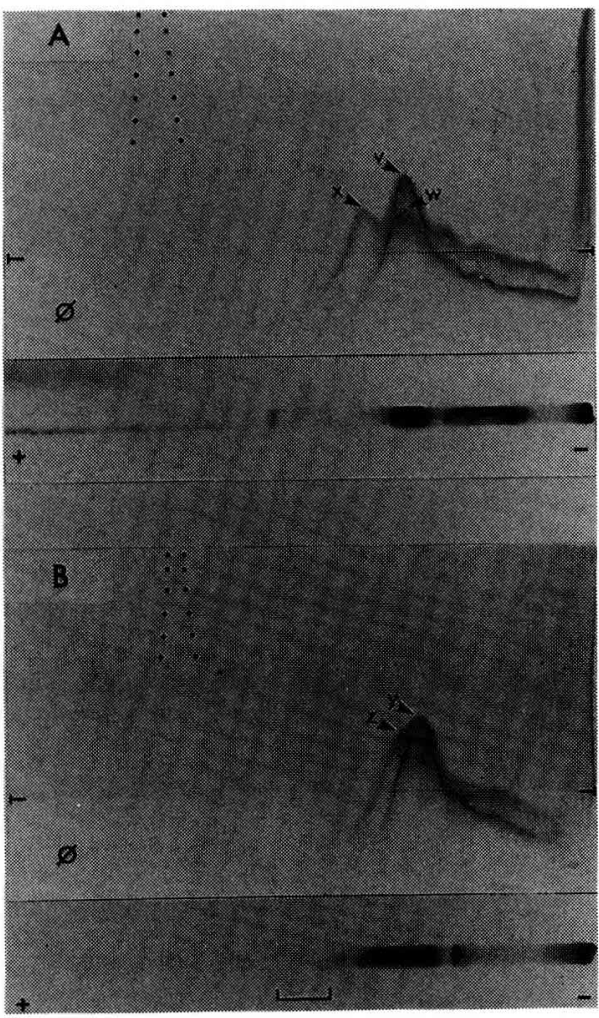

Fig. 5. Crossed immunoelectrofocusing of prepupae of $M$. rotundata and $M$. relativa to correlate compenents of 2D-PAGE and CIE analyses. Polypeptides separated in a first dimension isoelectric focusing polyacrylamide gel were run through an intermediate gel containing $1 \%(w / v)$ Triton $X-100(\theta)$ into a second dimension gel containing $0.5 \%(\mathrm{w} / \mathrm{v})$ Triton X-100 and $600 \mu \mathrm{l}$ of antibodies to prepupae of $M$. rotundata. Second dimension electrophoresis was at $2 \mathrm{~V} \cdot \mathrm{cm}^{-1}$ for $18 \mathrm{~h}$. The anode is to the left and top of the gels. The position of a weak immunoprecipitate not visible in the protographs has been indicated by a dotted line. A, M. rotundata prepupae; B, $M$. relativa prepupae. Bar represents $1 \mathrm{~cm}$.

11 polypeptides was not possible. In the present analysis, the quantitative evaluation of fluctuations during pupation of all 6 antigens was possible. Thus the $\mathrm{CIE}$ analysis resolved fewer components but, unlike 2D-PAGE, provided a convenient quantitative evaluation of resolved components. CIE analyses were rapid, inexpensive, and reproducible. The number of immunoprecipitates observed was consistent with the general observation of the previous 2D-PAGE analyses that polypeptide 1 accounted for greater than $25 \%$ of the prepupal protein, a situation analogous to that of the storage protein in Calliphora ssp. (Levenbrook and Bauer, 1980). In addition, the spot sizes of 4 additional polypeptides were greater than the other numerous minor polypeptides. Due to the relatively high concentration of these 5 polypeptides, the immunological response of rabbits injected with prepupal homogenates could be expected primarily to produce antibodies to only a few major proteins.

Solubilization of homogenates with a neutral detergent during immunization and CIE insured the analysis of both soluble and membrane-bound antigens. Thus the 7 immunoprecipitates defined by $\mathrm{CIE}$ represent the major protein antigens of the prepupae. The previous 2D-PAGE analysis monitored the total prepupal and pupal protein. The two analyses should therefore identify some of the same protein fluctuations. The polypeptides 1 and 4 of the 2D-PAGE analysis could be tentatively associated with the antigens identified in peaks 2 and 6 , respectively, of the present CIE analysis. The peak 2 polypeptide was previously shown to have an apparent $M r$ of 107,000 and a pl of 6.55 (Rank et al., 1982) and appears to be a major prepupal storage protein that is shunted into other proteins during pupation. The precise function and biochemical properties of the 6 antigens remains to be determined. In situ histochemistry, using intermediate gel techniques such as lectin binding and detergent charge shift will enable the further 
characterization of these antigens. Such analyses, coupled with the quantitative evaluation of peak areas, should provide insight into the role of the major protein species during diapause development.

These results suggest that antigen 2 of the present analysis is an important marker for the field emergence of a second generation. The polypeptide carrying antigen 2 was shown by this analysis and by 2D-PAGE to dramatically decrease in content during pupation. Cells destined to become second-generation aduits should be identifiable before morphological differentiation by a decrease in this important molecular marker. CIE will allow monitoring of the environmental induction of this trait at the molecular level and to compare the rate of diapause development between univoltine and multivoltine strains.

\section{References}

Arlian L.G., Runyan R.A., Sorlie L.B., Vyszenski-Moher D.L. \& Estes S.A. (1985) Characterization of Sarcoptes scabiei var. canis (Acari: Sarcoptidae) antigens and induced antibodies in rabbits. J. Med. Entomol. 22, 321-323

Crowle A.J. \& Cline J. (1977) An improved stain for immuno-diffusion tests. J. Immunol. Methods 17, 379-381

Einarsson R., Karlsson R., Olsson B., Uhlin T. \& Ohman S. (1985) Crossed immunoelectrophoresis and crossed radioimmunoelectrophoresis analysis of "Yellow Jacket Common Wasp" (Vespula ssp.). Allergy 40, 257-263

Gerlach J.H., Bjerrum O.J. \& Rank G.H. (1982) Electroimmunochemical analysis of plasma membrane vesicles from Saccharomyces cerevisiae. Can. J. Biochem. 60, 659-667

Harboe N. \& Inglid A. (1973) Immunization, isolation of immunoglobulins and estimation of antibody titre. Scand. J. Immunol. 2, Suppl. 1, 161-164

Johansen C.A. \& Eves J.D. (1973) Effect of chilling, humidity and seasonal conditions on emergence of the alfalfa leafcutting bee. Environ. Entomol. 2, 23-26

Laurell C.-B. (1966) Quantitative estimation of proteins by electrophoresis in agarose gel containing antibodies. Anal. Biochem. 15, 45-52

Levenbrook L. \& Bauer A.C. (1980) Calliphorin and soluble protein of haemolymph and tissues during larval growth and adult development of Calliphora vicina. Insect. Biochem. 10, 693-701

Lind P. (1980) Standardization of mite extracts. Qualitative and quantitative investigations of three kinds of preparations with CRIE and RAST. Allergy 35, 227-230

Rank G.H. \& Goerzen D.W. (1981) Native leafcutter bee species and associated parasites in commercial hives in Saskatchewan, Canada. Apidologie 12, 211-220

Rank G.H., Robertson A.J. \& Gilmer S.M. (1982) An analysis of major protein species during pupation in Megachile rotundata. Insect Biochem. 12, 699-705

Robertson A.J., Gerlach J.H., Rank G.H. \& Fowke L.C. (1980) Yeast cell wall, membrane, and soluble marker polypeptides identified by comparative two-dimensional electrophoresis. Can. J. Biochem. 58, 565-572

Taséi J.-N. (1982) Status of Megachile rotundata F. in France. Proc. 1st Intern. Symp. Alfalfa Leafcutting Bee Management, Saskatoon, 239-258

Taséi J.-N. \& Masure M.M. (1978) Sur quelques facteurs influençant le développement de Megachile pacifica Panz. (Hymenoptera, Megachilidae). Apidologie 4, 273-290

Vandenberg J.E., Fichter B.L. \& Stephen W.P. (1980) Spore load of Ascophaera species on emerging adults of the alfalfa leafcutting bee, Megachile rotundata. Appl. Environ. Microbiol. 39, 650-655 